\title{
The glial trees
}

I will chop the mesquite today. Autoclave the axe at $121^{\circ} \mathrm{C}$,

Soft tissue blade.

And till the beds, leaving

The furrows of your brain to fallow:

A grey, nitrate-sucking matter.

To arbitrate

Between arteries and roots.

With my pinking-shears.

Deep pause.

For the Winged Reaper who will burn this malignant tare.

No. The axe is laid unto the root.

I will chop the mesquite today.

Autoclaved the axe at $121^{\circ} \mathrm{C}$.

And the weight-bearing exercise sprigs

Osteoblasts from the dry chunk-bark - mixing

Mud and skull.

Inoperable! The iron mocks between my strawberry hands,

Which pray

That I will regret having sold

Your black appaloosas.

Aren't you proud to see me fell it?

As if your body still were able to trim and

Sing, and muck the stalls.

Here, a widening hole, undaunted

By my surgical knots, brimming

With the blood from last night's monsoon.

$\mathrm{Oh}$ ! In the angiogenesis,

There were romantic intentions and, 100 acres of myelin sheath.

How did we come here, to

This desert. And how do we exit but By the white lightning's crack.

\section{Emma Zimmerman}

Correspondence to Emma Zimmerman, McGill University, Montreal, OC, Canada; elzimme@gmail.com

Contributors EZ is the sole contributor to this poem.

Competing interests None.

Provenance and peer review Not commissioned; internally peer reviewed.

Published Online First 13 March 2012

Med Humanit 2012;38:e3. doi:10.1136/medhum-2011-010135 